\title{
Photocatalytic Degradation of Reactive Yellow Dye in Wastewater using $\mathrm{H}_{2} \mathrm{O}_{2} / \mathrm{TiO}_{2} / \mathrm{UV}$ Technique
}

\author{
Noor A. Mohammed ${ }^{a}$, Abeer I. Alwared ${ }^{a}$ and Mohammed S. Salman
}

${ }^{a}$ Department of Environmental Engineering/College of Engineering/University of Baghdad

${ }^{b}$ Avi-Cenna E-learning Center / University of Baghdad

\begin{abstract}
In the present study, advanced oxidation treatment, the $\mathrm{TiO}_{2} / \mathrm{UV} / \mathrm{H}_{2} \mathrm{O}_{2}$ process was applied to decolorisation of the reactive yellow dyes in aqueous solution. The UV radiation was carried out with a $6 \mathrm{~W}$ low-pressure mercury lamp. The rate of color removal was studied by measuring the absorbency at a characteristic wavelength. The effects of $\mathrm{H} 2 \mathrm{O} 2$ dosage, dye initial concentration and $\mathrm{pH}$ on decolorisation kinetics in the batch photoreactor were investigated. The highest decolorisation rates were observed (98.8) at $\mathrm{pH}$ range between 3 and 7. The optimal levels of $\mathrm{H}_{2} \mathrm{O}_{2}$ needed for the process were examined. It appears that high levels of $\mathrm{H}_{2} \mathrm{O}_{2}$ could reduce decolorisation by scavenging the $* \mathrm{OH}$. The color degradation rate decreases as the dye concentration increases. The rate coefficient $\left(\mathrm{k}=0.0319 \mathrm{~min}^{-1}\right)$ of degradation, follows the pseudo-first-order kinetics.
\end{abstract}

Keywords: Reactive Yellow dye; Titanium dioxide; Hydrogen peroxide; Advanced oxidation processes

Received on 13/05/2019, Accepted on 08/07/2019, published on 30/03/2020

https://doi.org/10.31699/IJCPE.2020.1.3

\section{1- Introduction}

In recent years, the treatment of textile and dyeing wastewater coming from textile industries and other related industries has received the increasing attention because of the high yield, low biodegradability and the high toxicity of this wastewater. The artificial dyes are organic compounds with complex molecular structures and big molecular weights, which are using in chemical industries especially in the textile industry. Most of them are considered non -toxic, although some of them are not totally innocuous because they made of known carcinogens such as benzidine [1]. The pollution problem is different for the various types of fibers. Color is the first contaminant to be recognized in the wastewater and has to be removed before discharging into water bodies or on land. The presence of very small amounts of dyes in water (less than $1 \mathrm{ppm}$ for some dyes) is highly visible and affects the aesthetic merit, water transparency and gas solubility in lakes, rivers and other water bodies [2] Therefore, it is necessary to find an effective method of wastewater treatment in order to remove the color from textile effluents. There are different convention methods, such as chemical precipitation and separation of pollutants, electrocoagulation [3], elimination by adsorption on activated carbon etc., are currently used. One difficulty with these methods is that they are not destructive but only transfer the contamination from one phase to another, therefore a new and different kind of pollution is faced and further treatments are deemed necessary [4]-[7].
Advanced oxidative processes (AOPs) offer a possible solution to this problem. They allow the degradation of pollutants by highly oxidizing species, such as hydroxyl radicals, generated in the reaction medium. The most widely used techniques are Fenton and photo-Fenton reactions [8],[9], $\mathrm{UV} / \mathrm{H}_{2} \mathrm{O}_{2}, \mathrm{UV} / \mathrm{O}_{3}$ and $\mathrm{O}_{3}$ systems [10] and heterogeneous photocatalysis with metal oxides such as $\mathrm{Ti}$ and $\mathrm{Zn}[11]$.

Among AOPs, heterogeneous photocatalysis using $\mathrm{TiO}_{2}$ as photocatalyst appears as the most emerging destructive technology [12]. The aim of the present work is to investigate the influence of various parameters on photocatalytic decomposition of an azo dye, called Reactive Yellow (RY) also to evaluate the degradation efficiency of simulated textile wastewater. The effect of the addition of $\mathrm{H}_{2} \mathrm{O}_{2}$ was also studied for enhancing of azo dye and the presence of unsupported suspended $\mathrm{TiO}_{2}$ powder, which is irradiated by the UV-C light. Heterogeneous photocatalysis has been shown to be potentially advantageous as it may lead to the complete mineralization of pollutants to $\mathrm{CO}_{2}$, water, and mineral acids [13].

\section{2- Experimental}

\subsection{Materials}

The commercial azo dye Reactive Yellow, (RY), Fig. 1, obtained from AL-Hilla textile factory south of Baghdad, (Department of Dying and Printing). 
TiO2-P25, powder supplied by Fluka (china) with $99 \%$ purity (molecular weight $79.87 \mathrm{~g} / \mathrm{mol}$ ). The hydrogen peroxide $(50 \% \mathrm{w} / \mathrm{w})$ was obtained from Merck. The natural $\mathrm{pH}$ of the aqueous dye solution was 7 . The experimental solutions were adjusted to the decided $\mathrm{pH}$.

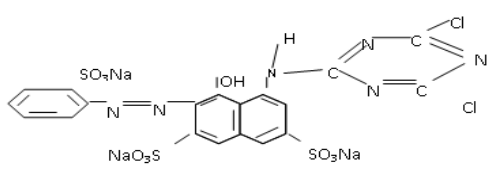

Fig. 1. Chemical Structure of reactive yellow [14], [15], [16]

\subsection{Irradiation experiments}

All photocatalytic and photochemical experiments were carried out in a batch mode laboratory-scale reactor. The reactor consisted of Pyrex glass cylinder $3 \mathrm{~L}$ volume with a magnetic stirrer and (MSH-300N, BOECO, Hamburg, Germany). UV radiation (254 $\mathrm{nm}$ ) was generated from a UV lamp (TUV 6 W 4P-SE, Philips, Guildford, Surrey, England), which was fixed vertically at the top of the reactor. The lamp was totally immersed in the content of the cylindrical reactor.

The UV lamp was sheathed in a quartz sleeve for protection. The distance between the lamp and the reactor wall was fixed at $5 \mathrm{~cm}$ to ensure maximum light irradiation. The turbidity of the solution was measured using a turbidity meter (Hanna microprocessor, Padua, Italy). The initial $\mathrm{pH}$ of the solution was monitored using a pH meter (INOLAB 72, WTW Co., Weilheim, Germany).

\subsection{Procedure and Analysis}

The desired concentration of dye's stock (20, 50, 75 and $100 \mathrm{mg} / \mathrm{L}$ ) was prepared and the $\mathrm{pH}$ was adjusted, before adding the reagents, by adding a dilute solution of $\mathrm{HCl}$ or $\mathrm{NaOH}$ to the reactor contents. $\mathrm{TiO} 2$ was added to the solution with $(25,50,75$ and $100 \mathrm{mg} / \mathrm{L})$ and then the hydrogen peroxide $(100,250,400$ and $700 \mathrm{mg} / \mathrm{L})$.

The solution was then subjected to stirring using a magnetic stirrer at $200 \mathrm{rpm}$ for $120 \mathrm{~min}$. The suspension was magnetically stirred in the dark for 16 min to attain primary adsorption equilibrium between dye and $\mathrm{TiO}_{2}$. $\mathrm{H}_{2} \mathrm{O}_{2}$ was added after that. Then, the lamp was switched on to initiate the reaction. During irradiation, agitation was maintained to keep the suspension homogenous.

Irradiation was carried out in the open-air condition. At specific time intervals, $10 \mathrm{ml}$ of the sample was withdrawn and centrifuged at (3000 rpm for $15 \mathrm{~min})$ to separate the catalyst. The concentration of dye in each sample was determined by a spectrophotometer (UV-Vis Spectrophotometer Perkin-Elmer 55 OSE) at $\lambda \max =420$ $\mathrm{nm}$ and a calibration curve Fig. 2 The percentage of decolorization was calculated as follows:
Decolorization $\%=\frac{\left(C_{o}-C\right)}{C_{o}} \times 100 \%$

Where: $C_{o}=$ initial concentration of dye solution.

$C=$ final concentration of dye solution.



Fig. 2. Calibration curve in wavelength $420 \mathrm{~nm}$

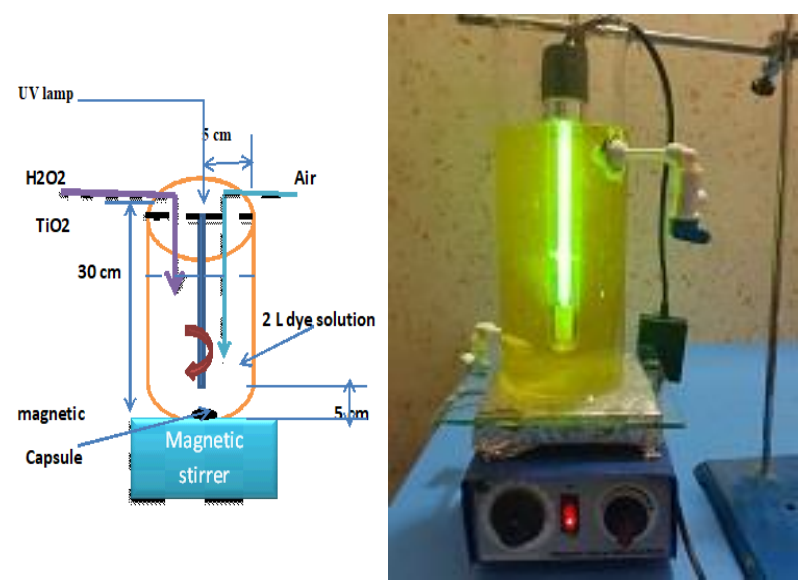

Fig. 3. Photograph and Schematic diagram of the batch reactor

\section{3- Results and Discussion}

\subsection{Effect of Initial RY-14 Concentration}

The effect of the initial concentration of RY -14 dye on the photocatalytic efficiency was investigated with concentrations ranging from 20 to $100 \mathrm{mg} / \mathrm{l} \mathrm{Fig.} 4$ at $\mathrm{TiO}_{2}=25 \mathrm{mg} / \mathrm{l}, \mathrm{H}_{2} \mathrm{O}_{2}=400 \mathrm{mg} / \mathrm{l}$ and $\mathrm{pH}=7$. From this figure, the sample was taken after $10 \mathrm{~min}$ from the experiment began; it was observed that the photodegradation conversion of RY-14 decreases with an increase in the initial concentration of RY. The presumed reason is that when the initial concentration of dye is increased, more and more dye molecules are adsorbed on the surface of $\mathrm{TiO}_{2}$. A large amount of adsorbed dye is thought to have an inhibitive effect on the reaction of dye molecules with photogenerated holes or hydroxyl radicals, because of the lack of any direct contact between them. Once the concentration of dye is increased, it also causes the dye molecules to absorb light and the photons never reach the photocatalyst surface, thus the photodegradation efficiency decreases [17]. 


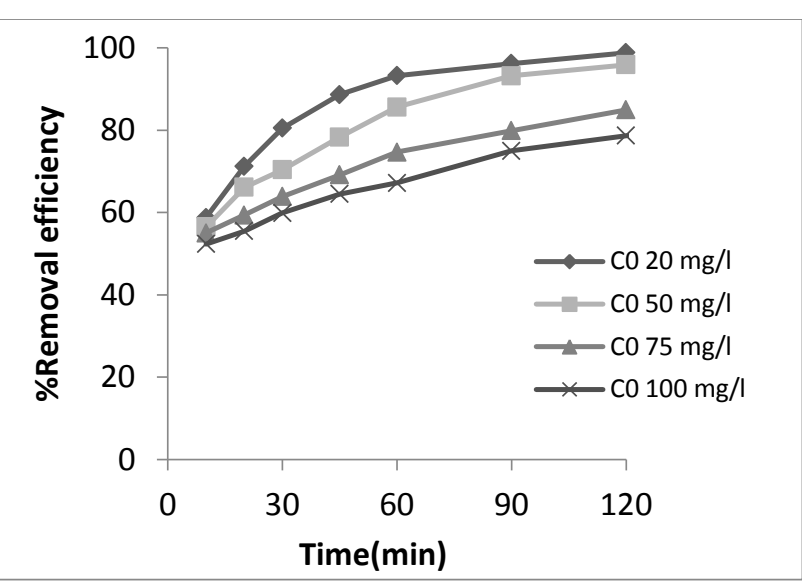

Fig. 4. Influence of initial RY dye concentration on dye degradation by the photocatalytic system at $\mathrm{H}_{2} \mathrm{O}_{2}=400$ $\mathrm{mg} / \mathrm{L}, \mathrm{TiO}_{2}=25 \mathrm{mg} / \mathrm{L}$ and $\mathrm{pH}=7$

\subsection{Effect of The Amount Of Photocatalyst}

The effect of the amount of $\mathrm{TiO}_{2}$ on the RY removals was studied at a concentration $(25,50,75$ and 100$) \mathrm{mg} / \mathrm{l}$ while keeping other parameters constant $(\mathrm{C}=20 \mathrm{mg} / \mathrm{l}$, $\mathrm{H}_{2} \mathrm{O}_{2}=400 \mathrm{mg} / \mathrm{l}, \mathrm{PH}=7$ ), and their results were plotted as shown in Fig. 5. The photodegradation efficiency increases with an increase in the amount of photocatalyst reach the higher value of catalyst amount $(25 \mathrm{mg} / \mathrm{l})$ and then decreases. The most effective decomposition of RY was observed with $25 \mathrm{mg} / 1$ of $\mathrm{TiO}_{2}$. The reason of this observation is thought to be the fact that when all dye molecules are adsorbed on $\mathrm{TiO}_{2}$, while the $\mathrm{TiO}_{2}$ is exposed to UV light, the conduction band electrons ( $\mathrm{e}^{-}$) and valence band holes $(\mathrm{h}+)$ are generated with light energy greater than its bandgap energy $(\mathrm{Eg}, 3.2 \mathrm{eV}), \mathrm{Eq}$. (2-5) .The photogenerated electrons could reduce the dye or react with electron acceptors such as $\mathrm{O}_{2}$ adsorbed on the $\mathrm{TiO}_{2}$ surface or dissolved in water, reducing it to superoxide radical anion $\mathrm{O}_{2}{ }^{-}$. The photogenerated holes can oxidize the organic molecule to form $\mathrm{R}^{+}$or react with $\mathrm{OH}^{-}$or $\mathrm{H}_{2} \mathrm{O}$ oxidizing them into $\mathrm{OH}^{*}$ radicals. Together with other high oxidant species (peroxide radicals) they are reported to be responsible for the heterogeneous $\mathrm{TiO}_{2}$ photodecomposition of organic substrates as dyes, refers to Eq. (6-9). The addition of higher quantities of $\mathrm{TiO}_{2}$ would have no effect on the degradation efficiency. Another cause for this is supposedly an increased opacity of the suspension works as a shading effect, brought about as a result of an excess of $\mathrm{TiO}_{2}$ particles [18], [19].

$$
\begin{aligned}
& \mathrm{TiO}_{2}+h v(\lambda<390 \mathrm{~nm}) \rightarrow \mathrm{TiO}_{2}(\mathrm{e}-\mathrm{CB}+\mathrm{h}+\mathrm{VB}) \\
& \mathrm{TiO}_{2}(\mathrm{hVB}+)+\mathrm{H} 2 \mathrm{O} \rightarrow \mathrm{TiO}_{2}+\mathrm{H}++\mathrm{OH} \bullet \\
& \mathrm{TiO}_{2}(\mathrm{hVB}+)+\mathrm{OH}^{-} \rightarrow \mathrm{TiO}_{2}+\mathrm{OH} \bullet \\
& \mathrm{TiO}_{2}(\mathrm{eCB}-)+\mathrm{O}_{2} \rightarrow \mathrm{TiO}_{2}+\mathrm{O}_{2} \bullet- \\
& \mathrm{O}_{2}^{\bullet-}+\mathrm{H}+\rightarrow \mathrm{HO}_{2} \bullet \\
& \text { Dye }+\mathrm{OH} \bullet \rightarrow \text { degradation products }
\end{aligned}
$$

Dye $+\mathrm{hVB}+\rightarrow$ oxidation products

Dye $+\mathrm{eCB}^{-} \rightarrow$ reduction products



Fig. 5. Effect of initial titanium dioxide $\left(\mathrm{TiO}_{2}\right)$ concentrations on dye degradation by the photocatalytic system at $\mathrm{H}_{2} \mathrm{O}_{2}=400 \mathrm{mg} / \mathrm{L}$, dye concentration $20 \mathrm{mg} / \mathrm{L}$ and $\mathrm{pH}=7$

\subsection{Effect of the Initial $\mathrm{pH}$}

In order to study the effect of the initial $\mathrm{pH}$ in the photocatalytic process, different values of $\mathrm{pH}(3,5$, 7,10and 11) were carried out at $\mathrm{H}_{2} \mathrm{O}_{2}=400 \mathrm{mg} / \mathrm{L}$, dye conc. $=20 \mathrm{mg} / \mathrm{L}, \mathrm{TiO}_{2}=25 \mathrm{mg} / \mathrm{L}$ and there results shown in Fig. 6, from this figure it can be noticed that the removal efficiency increases to reach a maximum of $98.85 \%$ at $\mathrm{pH}=7$ because the difference between the degree of photodegradation of RY in acidic solution ( $\mathrm{pH}=3$ and neutral $\mathrm{pH}=7$ ) was only $4 \%$, the following experiments were carried out with neutral $\mathrm{pH}$, this agrees with the previous study by [20].

This may be attributed to the electrostatic interactions between the positive catalyst surface and dye anions leading to the strong adsorption of the latter on metal oxide support .

The interpretation of $\mathrm{pH}$ effects on the efficiency of dye photodegradation process is very difficult task because of its multiple roles, this is because three possible reaction mechanisms can contribute to dye degradation, (1) hydroxyl radical attack, (2) direct oxidation by the positive hole, and (3) direct reduction by the electron in the conducting band. The contribution of each one depends on the substrate nature and $\mathrm{pH}$ [21].

Moreover, the positive holes are considered as the major oxidation species at low $\mathrm{pH}$ which react with hydroxide ions forming hydroxyl radicals, thus the efficiency of the process is enhanced. With high $\mathrm{pH}$, there is Columbia repulsion between the negatively charged surface of the catalyst and the hydroxide anions which prevent the formation of $\mathrm{OH}^{\circ}$ and decrease the photocatalytic degradation [22]. 


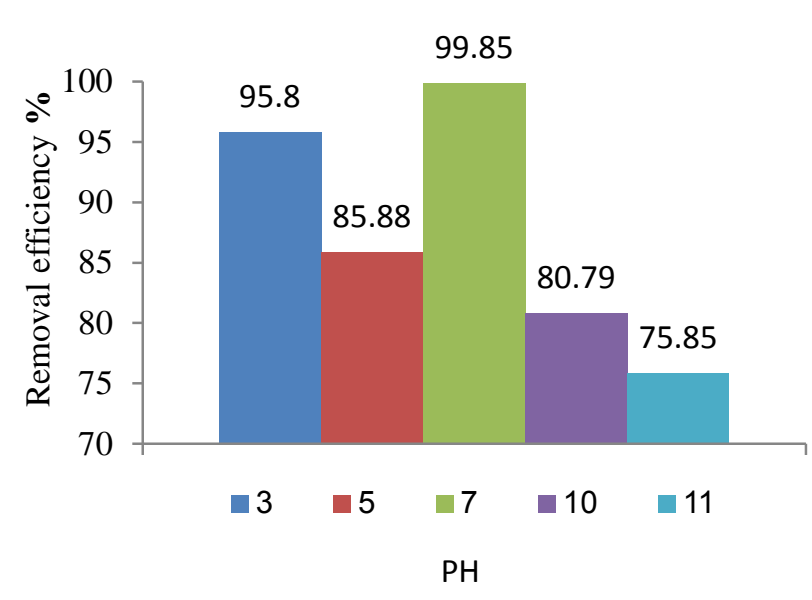

Fig. 6. Effect of $\mathrm{pH}$ on dye degradation by the photocatalytic system at $\mathrm{H}_{2} \mathrm{O}_{2}=400 \mathrm{mg} / \mathrm{L}$, dye concentration $20 \mathrm{mg} / \mathrm{L}$ and $\mathrm{TiO}_{2}=25 \mathrm{mg} / \mathrm{l}$

\subsection{Effect of Addition of $\mathrm{H}_{2} \mathrm{O}_{2}$}

The photocatalytic degradation of RY was a focus in this study at different hydrogen peroxide concentrations up to $(400 \mathrm{mg} / \mathrm{l})$, the results are given in Fig. 7 .

The higher reaction rates after the addition of peroxide were attributed to the increase in the concentration of hydroxyl radicals.

At a low concentration of hydrogen peroxide, it inhibits the electron-hole recombination, according to Eqn. 10, and it could act as an alternative electron acceptor to oxygen Eqn11 because hydrogen peroxide is a better electron acceptor than molecular oxygen according to Eqn. 12 this agrees with the previous study by [23].

The degradation rate of RY increased with increasing $\mathrm{H}_{2} \mathrm{O}_{2}$ concentration up to $400 \mathrm{mg} / \mathrm{l}$, but above this value there was a decrease in the degradation rate that could be due to by scavenging effect as $\bullet \mathrm{OH}$ according to Eqns.13and14 it became predominant, this agree with a previous study [24].

$\mathrm{TiO}_{2}(\mathrm{e}-)+\mathrm{H}_{2} \mathrm{O}_{2} \rightarrow \mathrm{TiO}_{2}+\mathrm{OH}-+\cdot \cdot \mathrm{OH}$

$\cdot \mathrm{O}^{-2}+\mathrm{H}_{2} \mathrm{O}_{2} \rightarrow \mathrm{OH}-+\cdot \mathrm{OH}+\mathrm{O}_{2}$

$\mathrm{H}_{2} \mathrm{O}_{2}+h v \rightarrow 2 \cdot \mathrm{OH}$

$\mathrm{H}_{2} \mathrm{O}_{2}+\cdot \mathrm{OH} \rightarrow \mathrm{HO}_{2} \bullet+\mathrm{H}_{2} \mathrm{O}$

$\mathrm{HO}_{2} \bullet+\cdot \mathrm{OH} \rightarrow \mathrm{H}_{2} \mathrm{O}+\mathrm{O}_{2}$

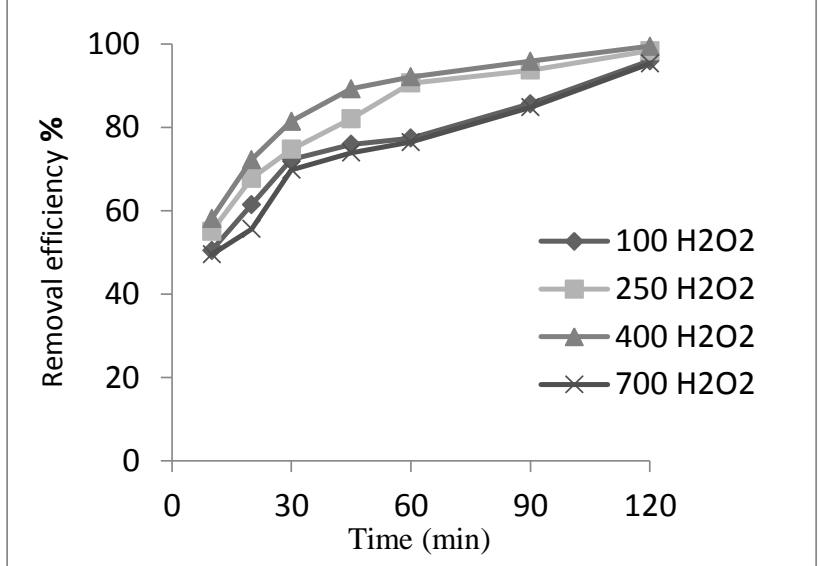

Fig. 7. Effect of $\mathrm{H}_{2} \mathrm{O}_{2}$ addition on photodegradation efficiency of RY-14 [RY] = $20 \mathrm{mg} / \mathrm{l}, \mathrm{TiO} 2=25 \mathrm{mg} / \mathrm{l}$, $\mathrm{pH}=7$

3.5. Reaction Rate Constant for Heterogeneous Photocatalyst

The experimental data for dye degradation can be fitted according to pseudo-first-order and pseudo-second-order. The linearized form of pseudo-first-order and secondorder kinetic models can be given in Eqn. (15) and (16) reported in [25].

$\ln \frac{\left[c_{0}\right]}{[c]}=\mathrm{K}$

$\frac{1}{[\mathrm{c}]}-\frac{1}{[\mathrm{c} 0]}=\mathrm{Kt}$

Where; Co is the initial concentration of dye and $\mathrm{C}$ is the concentration at irradiation time $\mathrm{t}, \mathrm{K}$ and $\mathrm{K} 1$ are the pseudo-first- and pseudo-second-order rate constants in $\mathrm{min}^{-1}$ and $\mathrm{L} \cdot \mathrm{mg}^{-1} \cdot \mathrm{min}^{-1}$, respectively , $\mathrm{t}$ is the irradiation time (in min). Plot of $\ln \frac{[c 0]}{[c]}$, and $\frac{1}{[C]}-\frac{1}{[\mathrm{C} 0]}$ versus time for each experimental lead to a straight line whose slope are $\mathrm{K}$ and $\mathrm{K}_{1}$, respectively [20]. The regression analysis of the concentration curves versus reaction time indicates that the decomposition rate of this compound could be described by 1 st - order kinetics. The results are summarized in Table $\mathbf{1}$.

Table 1. Reaction rate constants in heterogeneous photocatalyst

\begin{tabular}{ccccc}
\hline \multicolumn{5}{c}{${\text { Heterogeneous photocatalyst } ; \mathrm{H}_{2} \mathrm{O}_{2}=400 \mathrm{mg} / \mathrm{L}, \text { dye }=20 \mathrm{mg} / \mathrm{L}, \mathrm{pH}=7}^{\mathrm{TiO}_{2}=50 \mathrm{mg} / \mathrm{L}}$} \\
\hline $\begin{array}{c}\text { Removal } \\
\text { efficiency }\end{array}$ & $\begin{array}{c}\text { First order } \\
\mathrm{Kx10} 0^{3} \mathrm{~min}^{-1}\end{array}$ & $\mathrm{R}^{2}$ & $\begin{array}{c}\text { Second order } \\
\text { K1 } 10^{6} \mathrm{~L}_{\mathrm{mg}} \mathrm{mg}^{-1} \mathrm{~min}^{-1}\end{array}$ & $\mathrm{R}^{2}$ \\
98.8 & 0.0319 & 0.98 & 0.0328 & 0.8107 \\
\hline
\end{tabular}

\section{4- Conclusion}

$\mathrm{H}_{2} \mathrm{O}_{2} / \mathrm{TiO}_{2} / \mathrm{UV}$ was used to examine the performance of AOP for the degradation of RY dye wastewater. The reaction was influenced by the input concentration of $\mathrm{H}_{2} \mathrm{O}_{2}, \mathrm{pH}$, the amount of $\mathrm{TiO} 2$ and the concentration of $\mathrm{RY}$ in the wastewater. 
The addition of the proper amount of hydrogen peroxide could improve the photodegradation rate. However, at high concentrations, $\mathrm{H}_{2} \mathrm{O}_{2}$ would quench hydroxyl radicals. The reaction was found to be of a first-order throughout the systems. The removal efficiency for the system at best $\mathrm{H}_{2} \mathrm{O}_{2} / \mathrm{TiO}_{2} / \mathrm{UV}$ conditions and dosage $\left(\mathrm{H}_{2} \mathrm{O}_{2}=400 \mathrm{mg} / \mathrm{L}, \mathrm{pH}=7,, \mathrm{TiO} 2=25 \mathrm{mg} / \mathrm{L}\right)$ for $20 \mathrm{mg} / \mathrm{L}$ load was found to be $98.8 \%$.

\section{References}

[1] I. Faisal, "Removal of dyes from polluted water by adsorption on maize cob", ijcpe, vol. 11, no. 1, pp. 55-57, Mar. 2010.

[2] W. Taher Mohammed, H. F. Farhood, and A. Hassoon Bjaiyah Al-Mas'udi, "Removal of Dyes from Wastewater of Textile Industries Using Activated Carbon and Activated Alumina", ijcpe, vol. 10, no. 1, pp. 43-52, Mar. 2009.

[3] M. Yousuf, A. Molla, R. Schennach, J.R. Parga, D.L .Cocke ( 2001) ,Photocatalytic degradation of azo dye acid red 14 in water: investigation of the effect of operational parameters,J. Hazard. Mater. B, vol. 84, p.29.

[4] Huseyin Selcuk (2005) , Decolorization and detoxification of textile wastewater by ozonation and coagulation processes, Dyes and Pigments 64, p 217 222.

[5] N. Daneshvar, , D. Salari, , \& A. R. Khataee, "Photocatalytic degradation of azo dye acid red 14 in water on $\mathrm{ZnO}$ as an alternative catalyst to $\mathrm{TiO} 2 "$ ", Journal of photochemistry and photobiology A: chemistry 162.2-3 (2004): 317-322.

[6] W.S. Kuo, P.H. Ho, Solar "Solar photocatalytic decolorization of methylene blue in water." Chemosphere 45, no. 1, pp. 77-83 (2001).

[7] Garcia, J.C., Oliveira, J.L., Silva, A.E.C., Oliveira, C.C., Nozaki, J.,Souza, N.E., 2007. Comparative study of the degradation of real textile effluents by photocatalytic reactions involving $\mathrm{UV} / \mathrm{TiO} 2 / \mathrm{H} 2 \mathrm{O} 2$ and $\mathrm{UV} / \mathrm{Fe} 2+/ \mathrm{H} 2 \mathrm{O} 2$ systems. Journal of Hazardous Materials 147, 105-110.

[8] Pe'rez, M., Torrades, F., Domenech, X., Peral, J., 2002. Fenton and photo-Fenton oxidation of textile effluents. Water Research 36, 2703-2710.

[9] Azbar, N., Yonar, T., Kestioglu, K., 2004. Comparison of various advanced oxidation processes and chemical treatment methods for COD and color removal from a polyester and acetate fiber dyeing effluent. Chemosphere 55, 35-43.

[10] Rodrigues, A.C., Boroski, M., Garcia, J.C., Shimada, N.S., Nozaki, J.,Hioka, N., 2008. Treatment of paper pulp and paper mill wastewater by coagulationflocculation followed by heterogeneous photocatalysis. Journal of Photochemistry and Photobiology A: Chemistry ,vol.194, p.1-10.

[11] A.H. Mounteer, R.O. Pereira, A.A. Morais, D.B. Ruas, D.S.A. Silveira, D.B. Viana and R.C. Medeiros. (2007). Advanced oxidation of bleached eucalypt kraft pulp mill effluent ,Vol .55,No. 6, p. 109-116.
[12] Qamar, M., Saquib, M., Muneer, M.,(2005). Photocatalytic degradation of two selected dye derivatives, chromotrope $2 \mathrm{~B}$ and amido black 10B, in aqueous suspensions of titanium dioxide. Dyes and Pigments 65, 1-9.

[13] I.K. Konstantinou, T.A. Albanis, "TiO2-assisted photocatalytic degradation of azo dyes in aqueous solution: kinetic and mechanistic investigations: A review, Appl. Catal. B, vol. 49 ,p.1-14, 2004.

[14] Rachakornlij, M., Ruangch, S. and Teachakul, S., 2004, "Removal of Reactive Dyes from Aqueous Solution Using Bagasse Fly Ash", Journal of Science and Technology Thailand, vol. 26, No. 1, pp. 13-24.

[15] Manu, B. and Chaudhari, B. M., 2003,"Decolorization of Indigo and Azo Dyes in Semi Continuous Reactors" J. Process Biochemistry, March, vol. 38, Issue 8, pp. 12131221.

[16] E. M. Saggioro, A. S. Oliveira, T. Pavesi, C. G. Maia, L. F. V. Ferreiea, and J. C. Moreira, (2011).Use of Titanium Dioxide Photocatalysis on the Remediation of Model Textile Wastewaters Containing Azo Dyes, Molecules $\underline{16,10370}$

[17] Daneshvar N. , Salari D. , Khataee A.R., (2003) Photocatalytic degradation of azo dye acid red 14 in water : investigation of the effect of operational parameters , Journal of Photochemistry and Photobiology Chemistry vol. 157,p. 111-116

[18] V. Maurino, C. Minero, E. Pelizzetti, M. Vincenti, Coll. Surf. A , (1999) Chemical Processes in Marine Environments , 151, p.329.

[19] S.R. Cater, M.I. Stefan, J.R. Bolton, A. SafarzadehAmiri, (2000) ,Photocatalytic degradation of azo dye acid red 14 in water:investigation of the effect of operational parameters, Environ. Sci. Technol.,vol. 34, p. 659.

[20] M. Stylidi, D.I. Kondarides, X.E. Verykios, (2004) Visible light-induced photocatalytic degradation of Acid Orange 7 in aqueous TiO2 suspensions, Appl. Catal. B, vol. 47, p. 189-201.

[21]Rossetti, I. Compagnoni, M. Ramis ,G. Freyria, Francesca, (2017). Development of Unconventional Photocatalytic Reactors and Processes for the Abatement of Harmful N -containing Pollutants, Chemical Engineering Transactions, vol.57, p.319-324.

[22] Muruganandham, M., Sobana, N. and Swaminathan, M. (2006) Solar Assisted Photocatalytic and Photochemical Degradation of Reactive Black 5. Journal of Hazardous Materials, 137, 1371-1376.

[23] Lachheb, H., Puzenat, E., Houas, A., Ksibi, M., Elaloui, E., Guillard, C and Herrmann, J.-M. (2002) Photocatalytic Degradation of Various Types of Dyes (Alizarin S, Crocein Orange G, Methyl Red, Congo Red, Methylene Blue) in Water by UV Irradiated Titania. Applied Catalysis B: Environmental,vol. 39, p. 75-90.

[24] Chaudhuri, M., Elmolla, E. S. and Othman, R., 2009," Removal of Reactive Dyes from Aqueous Solution by Adsorption Coconut Coir Activated Carbon", 2nd International Conference on Engineering Technology (ICET 2009), December, Kuala Lumpur.

[25] F. M. Hameed and K. M. Mousa, "Study on Kinetic and Optimization of Continuous Advanced Oxidative Decolorization of Brilliant Reactive Red Dye", ijcpe, vol. 20, no. 1, pp. 9-14, Mar. 2019. 


\title{
ازالة الصبغة الصفراء الفعالة من مياه الملوثة المحضرة باستخدام تقنيه الاكسدة المقدمة
}

\author{
نور عبدالامير 1, عبير الورد 12 \\ أجامعة بغداد, كلية الهندسة, قسم العندسة البيئية \\ جامعة بغداد, مركز ابن سبيا
}

الخلاصة

في هذه الدراسة تم استخدام الاثعة فوق البنفسجية لازالة الصبغة الصفراء الفعالة من مياه الصرف الصحي

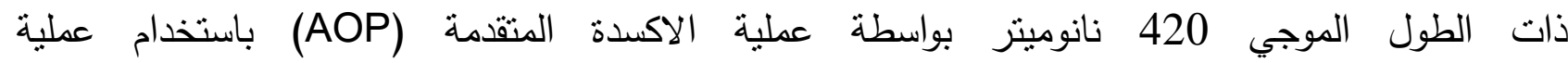
( وتم دراسة تاثير المتغيرات الرقم الهيدروجيني للمحلول وتركيز بيروكسيد الهيدروجين (TiO وتركيز الصبغة الابتدائي و تركيز ثنائي اوكسيد التيتانيوم (PH) الزمن min 120 ولوحظت أعلى معدلات إزالة اللون في نطاق الأس الهيدروجيني بين 3 و و 7.



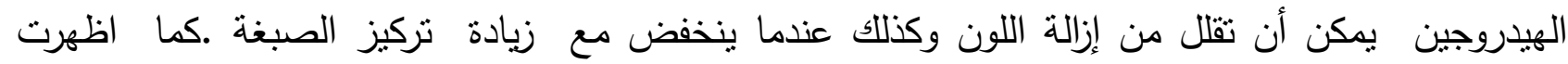

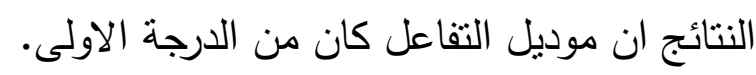

الكلمات الدالة: الصبغة الصفراء الفعالة, ثنائي اوكسيد التيتانيوم, بيروكسيد الهيدروجين, عملية الاكسدة المتقدمة 